\title{
Creating the Creative Post-political Citizen? The Showroom as an Arena for Creativity
}

\author{
By Richard Ek
}

\begin{abstract}
The aim of this article is to give a tentative illustration of how a creative, postpolitical citizen is imagined and encouraged to unfold within the frame of a city renewal project. As a starting point, the article outlines an exploratory framework structured through the analytical concept of postpolis. Postpolis is a term that offers an illustration of the distinguishing qualities of contemporary urbanity in a principal and schematic way. Postpolis here has three cornerstones: the idea of post-politics (the thesis that today politics is out-defined and replaced by governmental practices that leave little space for public influence and participation), the notion of biopolitics and the claim that planning is a governmental practice that is substantially influenced by business management approaches. The illustrative section of the article gives an overview of the empirical illustration $\mathrm{H}+$ and SHIP. $\mathrm{H}+$ is an urban regeneration project in the city of Helsingborg, in southern Sweden. As the largest urban regeneration project in Sweden to date, it will run for 30 years and affect about a third of the total area of the city. The showroom SHIP, which has been constructed in connection with this urban project, presents both what can be done and what is encouraged in tandem with an investigation of the functions, tasks and design of this showroom. The article thus initiates an ethnographic study of the showroom as a planning servicescape, in which the future citizen of Helsingborg is superimposed on the bodies of the visitors.
\end{abstract}

Keywords: Creativity, postpolis, performativity, urban regeneration, planning, showroom, democracy 


\section{Introduction - Pimp my City with Creativity!}

It is highly unlikely that a city planner or an urban developer would regard himor herself as a pimp for a specific city. It is, after all, not a very nice characterisation. But I begin with a provocative rhetoric because I want to engage immediately with the reader. The shift in planning philosophy that David Harvey at the end of the 1980s characterised as a shift in emphasis from the management and distribution of welfare resources to an emphasis on growth-oriented projects that were often speculative in nature (Harvey 1989) is now complete. Planning the city today is all about planning the consumer city: planning for consumption and economic growth. Cities in Europe and beyond are branded as places to consume, as destinations and centres for culture (to consume) and places to be consumed in (Miles 2010). The planning apparatus and the urban development and marketing discourses that permeate this apparatus can therefore - if not figuratively at least metaphorically - be regarded as a city pimp.

If we continue with the pimp metaphor, who are the 'Johns' the pimps want to attract? City marketing has traditionally been seen as a marketing practice with three objectives and target audiences: to attract new inhabitants of the city, to attract business investments and new companies and to attract tourists. But given that the shift towards growth-oriented speculative city development is now complete, this marketing picture no longer applies. As economic competition among cities becomes increasingly taken for granted, and the dominant notion is that it increases all the time, drastic measures are both legitimised and implemented. In practice, not every potential new citizen is welcome and not every business is attractive. Every tourist is welcome, however, even though some tourists, e.g. cruise tourists, are more welcome than others.

This decision about which potential citizens are welcome, as well as which kinds of businesses and companies are especially desirable to attract to the city, is based on global city development and urban regeneration discourses that travel in the cultural circuit of capitalism outlined by Nigel Thrift (2005). These discourses pivot on concepts that contain a semantic that is somewhat magnetic, vague and ambiguous but at the same time seemingly usable in a plethora of urban growth contexts (Magnusson 1994). One of these concepts is 'creativity', which in city management circumstances is perhaps primarily connected to the thesis on the creative class outlined by Richard Florida (2002). A large number of urban regimes (Stone 1989) have turned towards Florida with the plea to 'pimp our city!' More cities have followed the advice laid out in his books and of other marketing and creativity gurus in the consultancy field of city development and city branding (Kotler et al. 1993; Landry 2000 and 2006). As a result of the discourse's influence on the importance of creativity in city development, creative industries and businesses and supposedly creative people have been the prime target of urban policy and development and as the continuation in the city planning apparatus. The city is possible to 'pimp' through an inflow of creative 
people and, as this article will stress, through the creation of a creative citizen in a more general, biopolitical sense.

The aim of this article is to give a tentative illustration of how a creative, postpolitical citizen is imagined and encouraged to unfold within the frame of a city renewal project. As a starting point, the article outlines an exploratory framework structured through the analytical concept of postpolis. Postpolis is a term that offers an illustration of the distinguishing qualities of contemporary urbanity in a principal and schematic way (Tesfahuney \& Schough 2008). The concept does not imply that the city is no more, or that the metaphysical foundation of the polis does not apply ('post' does not signify a state of order 'after' polis), but that nowadays the city is in some fundamental sense qualitatively different from what traditional notions of polis have maintained (Soja 1989: 5).

The section that follows this introduction outlines the framework of the creative citizen through specific planning practices and technologies. Three aspects and subsections are highlighted. The first of these aspects is the idea of post-politics: the thesis that politics is now out-defined and has been replaced by governmental practices that leave little room for public influence and participation. The second subsection argues that the post-political contemporary is really biopolitics taken to a new level of intensity and extension (Dean 2007). The third subsection discusses how city planning, development and management have changed as a governmental practice in the last twenty years or so. Here, particular attention is directed towards how business management approaches and technologies have been imported and applied in the city planning apparatus. Space is also reserved for discussing how planning has remained a post-political practice, despite attempts to open up this governmental practice to the influence of citizens.

The third section of the article gives an overview of the empirical illustration $\mathrm{H}+$ and SHIP. $\mathrm{H}+$ is an urban regeneration project in the city of Helsingborg, in southern Sweden. Being the largest urban regeneration project in Sweden to date, it will run for 30 years and affect about a third of the total area of the city. In connection with this urban project, an exhibition hall - the showroom SHIP - has been constructed. In this exhibition space, the future urbanity of Helsingborg in general and the $\mathrm{H}+$ project in particular is materialised and visualised through different modalities of representations and performances. The fourth section is methodological and empirical in nature. First, brief recapitulations of Foucault's understanding of subjectification and Butler's idea of performativity are conducted and discussed in relation to the empirical illustration. The starting point here is that in the SHIP locale, the future (creative) citizen is discursively subjectified through performativity. Thus, a short visit to SHIP results in a presentation of what can be done and what is encouraged in tandem with an investigation of the functions, tasks and design of this showroom. The paper thus initiates an ethnographic study of the showroom as a planning servicescape in 
which the future citizen of Helsingborg is superimposed on the bodies of the visitors. The article ends with a concluding summary.

\section{Postpolis}

\section{Post-politics}

The concept of post-politics stems from Slavoj Žižek's reading of Jacques Rancière's work on political theory and the beginning of politics, the foundation of polis, in Aristotle (Rancière 1999). He differentiates between 'the police', 'politics' and 'the political'. The police is defined as a 'set of procedures whereby the aggregation and consent of collectivities is achieved, the organisation of powers, the distribution of places and roles, and the systems for legitimising this distribution' (Rancière 1999: 28). As a definition, Rancière's 'the police' is close to Foucault's notion of governmentality, a societal order that strives for the saturation of social space, a sutured society (Swyngedouw 2009: 606). Politics is whatever breaks with or stands in an antagonistic relation to the police, the configuration of societal order, and the expression of disagreement with the police order (Rancière 2000, 2001, 2004). The political is the discursive place in which politics is enunciated and the arena for the encounter between the logic of the polis order and the logic of politics (based on equality and disagreement). The political is thus a rare event in that it requires the presence of the principle of equality, although it can emerge from anywhere - like the disruption of the normalised social order can happen anywhere due to the fact that society never becomes totally sutured (Dikeç 2005). Politics is not simply the organisation of society or the usually assumed place of government, but the alternative to any police order (Rancière 2003). Further, politics is not only understood as technological approaches to decision-making and problem-solution in those governance constellations that thrive in the contemporary planning sphere (Swyngedouw 2005).

Slavoj Žižek sees the fact that the police order is mixed-up with politics as a sign of the times (Žižek 1998). In post-modern post-politics, the police order no longer merely 'represses' the political and tries to contain it and pacify the 'repressed', but much more effectively 'forecloses' it:

In post-politics, the conflict of global ideological visions embodied in different parties which compete for power is replaced by the collaboration of enlightened technocrats (economists, public opinion specialists...) and liberal multiculturalists; via the process of negotiation of interests, a compromise is reached in the guise of a more or less universal consensus. Post-politics thus emphasises the need to leave old ideological divisions behind and confront new issues, armed with the necessary knowledge and free deliberation that takes people's concrete needs and demands into account. (Žižek 1999: 198)

Post-politics is thus the administration and the management of people and society. Žižek explicitly argues that post-politics is 'the growth of a managerial approach 
to government: government is reconceived as a managerial function, deprived of its proper political dimension' (Žižek 2002: 303 in Swyngedouw 2009: 609, see also Žižek 2001). Žižek's interpretation of the post-political contemporary as a political theology echoes both the neoliberal theology of Fukuyama (1992) - it seems as though Fukuyama was right after all - and the conservative theology of Carl Schmitt (1976, 1985), which maintains that there is no longer a primary distinction between friend and foe (Vogt 2006) (there is also an affinity with the political agonism of Laclau and Mouffe). Instead, divisions between enemy and friend are replaced by an emphasis on every individual as a micropolitics of the everyday (Dean 2005). In the individualised, neoliberal contemporary, the requirement for the political decreases, i.e. the possibility of raising a particular issue to the level of the universal as a principal question (Dean 2009). In a postpolitical reading, homelessness, as an example, becomes an individual problem with a technical solution, whereas in the political proper, (to Žižek and others) homelessness is a structural, political problem that needs a political solution. Radical political change thus becomes impossible to imagine (when politics is emptied of its content). Yes, everything can, and is, criticised, but without taking the form of antagonism (Diken 2009a).

The post-political label thus functions as an umbrella concept; a dominant logic or explanation to a multitude of societal trajectories. To Diken and Laustsen, (asylum) politics becomes (risk) management, a sort of post-politics articulated within a wider discourse of securitisation (Diken \& Laustsen 2004 and 2005). In short, politics becomes a game where the rules can be changed all the time (Diken 2009b). Likewise, to Dahlstedt and Tesfahuney (2009), contemporary society works like a casino in which the rules of the post-political game are based on taking chances or risks in order to gain personal benefit in the short term. In this post-political game, the two forms of nihilism - a passive, reactive nihilism that expresses itself in ideas about the end of history (the credo of post-politics) and an active, affirmative nihilism that expresses itself in the spirit of the credit and profit maximisation - are united. Common to both forms of nihilism is that the Earth, life and humanity are subordinated, instrumental and economic values (ibid.). Life in the post-political contemporary is managed for another purpose, a higher purpose, than life itself. Here, post-politics shows itself as biopolitics taken to a new level.

\section{The Biopolitics of Postpolis}

In the post-political contemporary, when politics is foreclosed, bare life becomes the main object of politics as the post-political sovereign dissolves distinctions, thus creating zones of indistinction with the purpose of optimising the management of life (Agamben 1998; Diken 2009a). Here, the post-political relies on either including people in a consensual pluralist order or excluding people in a radical way (the inclusive exclusion) outside the consensus/post-political body 
(Swyngedouw 2008). Post-politics therefore brings with it a paradoxical violence; a violence of a society bent on neutralising negativity, dissent and revolutionary forces (Diken 2009a) that have been caught and developed by an authoritarian liberalism (Dean 2007). This is the violence of bio-power, and, as Foucault's writing informs us, is not a new phenomenon. By looking at the post-political through a biopolitical raster, an opportunity to approach matters of subjectification in the post-political contemporary unfolds. Rancière declares:
Politics is a matter of subjects or, rather, modes of subjectification. By subjectification I mean the production through a series of actions of a body and a capacity for enunciation not previously identifiable within a given field of experience, whose identification is thus part of the reconfiguration of the field of experience... Political subjectification produces a multiple whose count poses itself as contradictory in terms of police logic. (Rancière 1999: 35-36, original emphasis)

As is well known, Foucault's interest in subjectification had a more central role in his later work on ethics (Foucault 1978, 1985a \& 1985b). The process of selfmaking requires both breaking away from and approaching the discourses and norms that makes one a subject. Subjectivity is thus an effect of regimes of power/knowledge, perhaps especially the technologies of the self-like confession that people engage in. People scrutinise their behaviour and thinking by comparing themselves with the legitimate norms and ethics in society (ibid., see also Foucault 1997). Change is manifested in speech through avowal. Confession has had different functions throughout history (as Foucault illustrates in his investigation of the history of sexuality), but in the end subjectivity is explicitly understood as an ethical project. Discourses do not determine subjectivity. Rather, people construct themselves by choosing ways of actively governing themselves (Dean 1999). This construction is unfolded as a dialectic between subjectification and desubjectification, where desubjectification strengthens and energises subjectification. However, as this oscillation between subjectification and desubjectification is only implicitly postulated in Foucault's work and is therefore generally disregarded in works on subjectivity (Ek et al. 2007).

The construction of subjects, even if it is an agent-based construction, still needs to be seen through the lenses of biopolitics. To Foucault, bio-power found its forms in the 17th century as a power over life in two basic forms. The first concerned the body, its disciplining, optimisation, docility and the increase of its usefulness in systems of economic control. The second focused on the population (propagation, birth and mortality) (Foucault 1978: 139). To Foucault:

This bio-power was without question an indispensable element in the development of capitalism: the latter would not have been possible without the controlled insertion of bodies into the machinery of production and the adjustment of the phenomena of population to economic processes... If the development of the great instruments of the state, as institutions of power, ensured the maintenance of production relations, the rudiments of anatomo- and bio-politics, created in the eighteenth century as techniques of power present at every level of the social body and utilised by very diverse institutions (the family and the army, schools and the police, individual medicine and the administration of collective bodies), operated in 
the sphere of economic processes, their development, and the forces working to sustain them. (Foucault 1978: 140-141)

Observing the rise of a neoliberal ideology at the beginning of the 1980s, Foucault, together with some colleagues, continued to formulate the history of biopower as a more nuanced history of social regulation, where a 'liberal' political economy qualified/legitimised the Western practice of biopower (Hannah 2000: 22). The concept of governmentality was born from this work, as the ensemble 'formed by the institutions, procedures, analyses and reflections ... that allow the exercise of [the] very specific albeit complex form of power, which has as its target population, as its principal form of knowledge political economy, and as its essential technical means apparatuses of security' (Foucault 1991: 102). Governmentality became a concept for the conduct of conduct in the late 20th century in its neoliberal form, with an emphasis on the individual as consumer rather than citizen in constant interaction with market forces rather than with state apparatuses (Rose 1990, 1999, 2006; Barry et al. 1996; Dean 1999; Miller \& Rose 2008). Practices like city planning become embedded in the liberal conduct of conduct and unfold as discursive practices that aim to influence the citizen's formation of a subject. In sum, city planning is a biopolitical practice with the intention of creating a set of norms that then influences the process of subjectification at an individual level. However, this conclusion makes it necessary to investigate the practice of planning the postpolis further.

\section{Planning the Postpolis}

The planning apparatus and planning as an applied practice have changed in fundamental ways in recent decades. As this has been discussed at length in planning theory (see for instance Jensen and Richardson 2004) a summary is sufficient here. First, from a policy perspective spatial planning has become more ambitious and active when it comes to creating conditions for economic growth, even if the consequences of these actions have been spatial disparity and uneven development (Hudson 2001). The planning apparatus has become more businessand market oriented (Brenner 2000). For instance, private and corporate interests are invited to be a part of the spatial policy making and planning (Stubbs et al. 2002). A large number of new planning organisations - that are public-private in nature rather than purely public - have been founded (McGuirk 2000) based on the assumption that organisational solutions other than the public organisation are more capable of delivering a spatial policy and planning outcome that meets the requirements of a highly competitive geo-economic situation (Sparke 1998). New organisational solutions and approaches like multi-level governance and networking have emerged in the wake of these planning trajectories (Peters \& Pierre 1994), and several tools or techniques of ordering stemming from the sphere of private business, leadership and marketing have been applied within the 
planning apparatus: visioning, SWOT-analysis, bench marking and city marketing and branding.

City marketing and branding are especially interesting in this context. City marketing, or place marketing in general, has been around for quite some time, at least since the 1850s (Ward 1994). Despite this, relatively few cities were marketed until the beginning of the 1970s, when practically every city started to unleash marketing campaigns (Burgess 1982). Success stories like those of New York and Glasgow became examples that many cities tried to copy and apply (Ward 1998: 47). Of course, as specific representations of a geographic area, these marketing practices contain a poetics of power in terms of who is omitted, who is represented, how and so on. In several respects, the place marketing material became hyperrealist images that preceded the actual physical territories in a Baudrillardian way (Clarke \& Bradford 1989), saying more about the epistemologies of the marketers than the ontologies of the marketed spatialities (Barke and Harrop 1994). More recently, place branding and city branding have become new and fashionable concepts that also indicate a new approach towards the city in city planning. Rather than marketing the city as a city, it is branded as a brand. An urban branding process is about creating a brand that can serve as a framework for the city in its marketing process. City branding is therefore a more ambitious effort to sell a geographical area, based on branding techniques like brand loyalty and brand equity that have been incorporated from the private business sphere (Coaffee and Rogers 2008). But of course a problematic politics and poetics of representation do not only exist as whole cities. The city's population is also branded or marked as burnt offerings to tourists and the global creative business life of liquid modernity.

The fact that city branding as a planning practice has increased in scope has opened the way for branding experts and consultants like Simon Anholt (2007 and 2010) and enhanced the impression of planning practices as post-political. Planning has always been an issue for planners and experts within the different fields of city planning and development, not least due to its technological, and even technocratic, characteristics (Gunder 2010). In a way, planning practices embody the situation that Habermas (1984 and 1987) wanted to address with his theory of communicative action (the colonisation of life-worlds by instrumentality and rationality). His ideas have therefore been used by planning theorists calling for the argumentative turn in planning (Fischler 1995) and a communicative planning theory (Healey 1997). Even though communicative planning theory has had some influence on planning theory (for a critique, see Tewdwr-Jones \& Allmendinger 1998: 1977), there has not been a corresponding development in the planning apparatus:

Although these moves are welcome attempts to encourage more people to become involved in the day-to-day decision-making processes of local planning authorities and could therefore be described as 'bottom-up' to some degree, they are nevertheless undertaken within an institutional, political, and legal framework that 
remains 'top-down'. There is a degree of flexibility apparent, but when planners attempt to transpose stakeholders' desires into practical policy outcomes, experience has shown that it is the hierarchical regulatory and institutionalised planning context that wins the day. (Tewdwr-Jones \& Allmendinger 1998: 1978)

There are attempts, though, to make planning a practice that genuinely invites and includes the civil society, and there are opportunities in planning development project processes for the public and for civil groups to express their opinions on the issues at hand. But the research that has been conducted indicates that in practice public participation is often arranged and orchestrated in such a manner that the control of the process is always in the hands of the planning elite (Mitchell 1996 \& 1997; Stevenson 1999; McCann 2001 \& 2002). While there is a genuine ambition among (at least some) planners to engage the public - the citizens in the city - it is always on the terms of the planning practice and not on the terms of the political. In other cases (reasonably), dialogue with the public is something that is required by law, rather than something that is done out of a true interest in public opinion.

But by and large there is still an honest desire to engage the city population. The question is how? Here, I argue that the showroom fits in as a benevolently intended arena for interaction between planners and the public. At least in a Scandinavian context, showrooms (also an innovation from private business life) initially worked as exhibition halls that reflected a technological endeavour, as in the case of the exhibitions associated with the building of the Öresund Bridge (Ek 2003). These exhibitions spaces were permeated with visualised technology, or what could be described as a visual orgy of a future society entwined through a multitude of material and non-material modes of representation: computer animations, digital databases, aerial photos, films, photos, models, sounds and artefacts. In sum, these exhibition spaces of visual and panoptic gluttony became technological vision machines (Virilio 1994) that left little opportunity for people to interact with each other without such mediation. SHIP is not technological to the same extent, but is more based on 'social' (i.e. socio-material) mutual interaction between people/subjects. However, the crucial question is how this interaction is arranged and how the showroom is designed and functions. We will look at that in more detail after the presentation of the $\mathrm{H}+$ project and SHIP.

\section{Concluding Remarks on the Framework of Postpolis}

To round up this attempt to frame postpolis as an analytical concept, it can be said that postpolis is the city in which politics is based on the principle of krematistikos (pecuniary) rather than that of oikos (economise on resources). In the postpolis, the traditional primary function of the polis to harbour the agora and constitute a societal contract in order to create the qualified life (bios) no longer applies. Instead, the primary function of postpolis is growth (often expressed as the common good) through the mobilisation of all kinds of resources (often through accumulation by dispossession, see Harvey 2003). In this respect people are assets 
(Schough \& Mekonnen 2008), and when people are assets politics is no longer necessary and can be defined as something else, e.g. a moral issue (a question of right or wrong), as a concern for the market (an economic decision) or as a question of blood ties (Mouffe 2005). In practice, post-politics is unfolded as the management of biopolitical subjects. Planning is thus no longer about planning in society or the planning of society, since the society of polis becomes overshadowed by the principle of krematistikos. As Schough and Mekonnen (2008: 142) so cunningly paraphrase Margaret Thatcher: 'there is no such thing as an (urban) society'. Rather, planning is about creating a biopolitical subject that possesses certain qualities that make them useful in the postpolis of krematistikos. Creativity is such a quality and is both required and desirable. Indeed, planning practice finds its raison d'être in: 1) attracting creativity in the shape of people, investments and companies; 2) creating physical surroundings that facilitate the appearance of creativity; and 3) encouraging people to foster their creativity as an inherent part of the subjectification process. In the continuation of this article the latter two points are addressed further: empirically through the case of the urban renewal project of $\mathrm{H}+$ and its showroom SHIP and methodologically through the performativity approach as laid out by Judith Butler (1990 \& 1993).

\section{H+ and the Showroom SHIP}

As has already been indicated, the purpose of the $\mathrm{H}+$ project is to transform and develop Helsingborg's central southern district over a time span of 30 years. About one million square metres of former industrialised harbour will be renewed. The key to the transformation is the construction of the Söder Tunnel and the rerouting of the south-bound railway underground, which will open the central southern district to the sea and increase its attractiveness in several ways. About 4000-5000 new apartments are planned for, which implies about 10000 new inhabitants in the area. About $37 \%$ of the area will be reserved for activities like business and trade. The $\mathrm{H}+$ project is embedded in a city vision of Helsingborg as a tolerant and dynamic urbanity. The vision is based on five key concepts: availability, mosaic, sustainability and good health, experimentalism and crossbordering co-operation. Likewise, the project's environmental profile is laid out in five (different) key concepts: the resource-effective city, healthy and attractive environment, availability and urban mobility, water and green areas and sustainable urban lifestyle. The project also has a more strategic, regional purpose, namely to strengthen the northern part of the Öresund region and make Helsingborg a clearer and heavier counterpart to the region's southern centre consisting of the cities of Copenhagen, Malmö and Lund. Also here we find five specifications in the shape of slogan concepts. In a regional context, the $\mathrm{H}+$ project is expected to play an active role in the region by being a creative centre, a regional destination with its share of attractions, including activities and 
businesses with a regional sphere of action and to contribute to the realisation of a fixed connection to Denmark (Helsingborg City 2010). Another strategic ambition of the project is to reduce segregation in Helsingborg. The northern part of Helsingborg is the affluent part of the city, while the southern part is associated with exclusion, unemployment and misery. To some degree this picture is mirrored in socio-economic statistics, but not as much as in the public perception of the city as strongly divided (Högdahl 2007).

SHIP is presented as an arena for creativity and an exposé over the future of southern Helsingborg. It is a specially designed locality or showroom for the $\mathrm{H}+$ project's exhibition 'Think $\mathrm{H}^{+}$'. The intention is that the engaged citizen, or anyone else, will be able to receive the latest news regarding the $\mathrm{H}+$ project. SHIP has been in existence since the autumn of 2007 and is also a designed office hotel where small, innovative companies can rent office space and meeting facilities. A café is included in the building, offering fair trade beverages. ${ }^{1}$

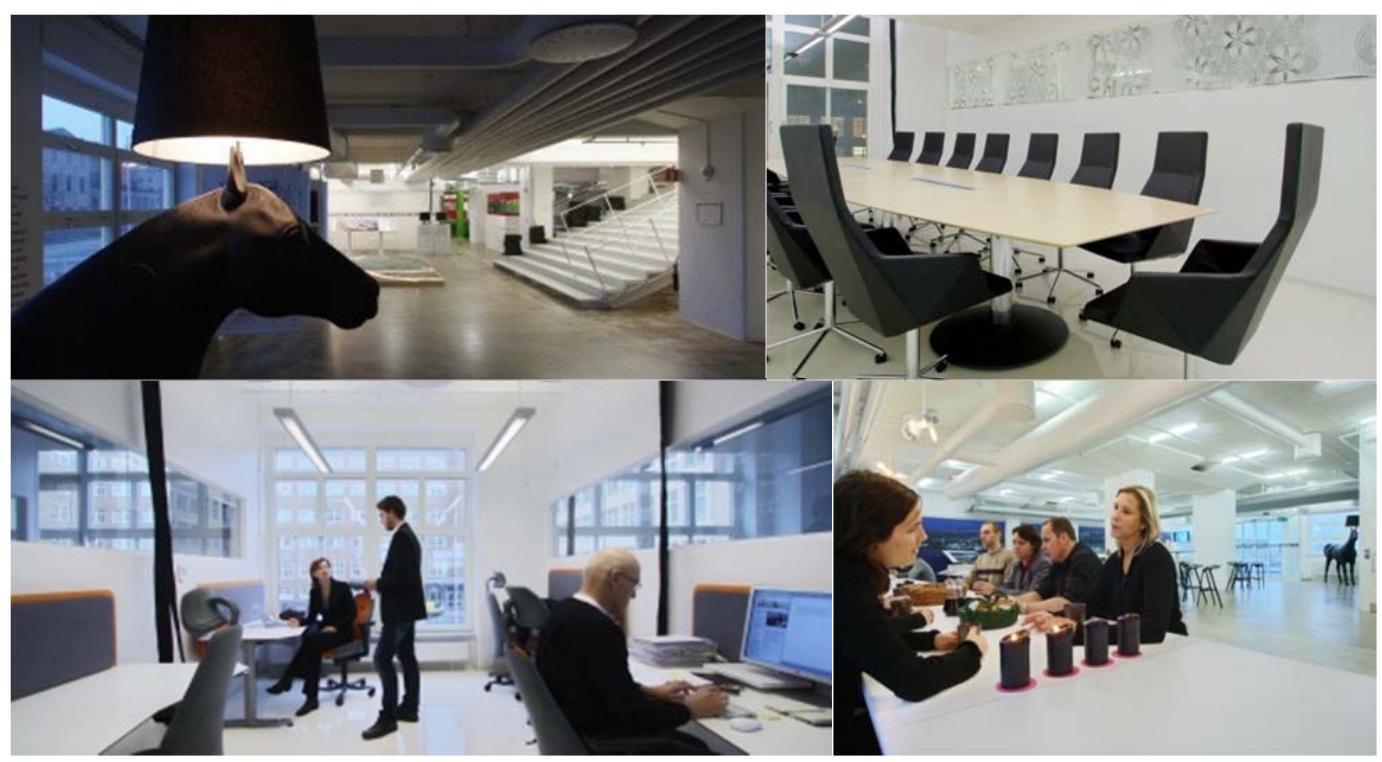

Pictures 1-4 All pictures from SHIP's website. ${ }^{2}$

\section{The Performative Power of the Showroom}

Judith Butler's work on performativity does not need any extensive recapitulation. As a theorist interested in the disruption of dominant understandings of the subject, she is a creative interlocutor of Foucault. In particular, Butler's 1997a and 1997b are ambitious attempts to develop Foucault's idea further (Gregson \& Rose 2000; McKinlay 2010). In Gender Trouble (1999: 185, original emphasis) she states that:

In other words, acts, gestures, and desire produce the effect of an internal core or substance, signifying absences that suggest, but never reveal, the organising principle of identity as a cause. Such acts, gestures, enactments, generally con- 
structed, are performative in the sense that the essence or identity that they otherwise purport to express are fabrications manufactured and sustained through corporeal signs and other discursive means. That the gendered body is performative suggests that is has no ontological status apart from the various acts which constitute its reality.

In another of her books, Bodies that Matter (1993) Butler develops this theory of agency by stressing that performativity is not a distinct act or event, but the 'reiterative and citational practice by which discourse produces the effects that it names' (Butler 1993:2). As performativity is a reiteration of norms that simultaneously dissimulates the norms or conventions of which it is a repetition, it cannot be understood as something that is outside the process of iterability and repetition and performed by the discourse rather than the subject per se. Language is thus in itself performative (Butler 1993: 30, original emphasis):

\begin{abstract}
If the body signified as prior to signification is an effect of signification, then the mimetic or representational status of language, which claims that signs follow bodies as their necessary mirrors, is not mimetic at all. On the contrary, it is productive, constitutive, one might even argue performative, inasmuch as this signifying act delimits and contours the body that it then claims to find prior to any and all signification.
\end{abstract}

Generally, interpretations of Butler's account of performativity have been divided into two camps. The first camp has discerned a potential for a new gender politics through the performative reconfiguration of gender norms, while the other camp has been more pessimistic about the possibilities for change (Mahtani 2004; Lloyd 2010). What can be read from this is that there is always room for manoeuvre within the discourses and systems of norms in which the performativity of agents is embedded, even if these possibilities of change and subversion can never be taken for granted. At the same time, there is a corresponding risk that nonnormative performances may reinforce normativity (Salih 2002; Lloyd 2010).

Performativity and the effects of performative action must thus always be seen as contextual, in terms of discourse and power - as well as spatially - where there is always the potential and capacity for norm-breaking identity construction. In this case, the showroom SHIP becomes a milieu or framed space that both enables and encourages specific performances at the same time as it disables and discourages other forms of behaviour and performances. Given that in some respects SHIP can be seen as a servicescape in a planning and urban renewal context, it also resembles a performativity-space that reflects the entire ontological register.

It then becomes crucial to actually observe what is going on in this 'planning space'; this servicescape for the engaged citizen who is interested in being part of the redevelopment of the city of Helsingborg. In view of this, a shorter ethnographic investigation was therefore conducted in which I was primarily interested in searching for: a) opportunities and limitations relating to creative conduct and b) to what degree the design of the showroom allowed for active political engagement with the concretised planning vision. Assuming the role of a 
general visitor, I visited SHIP with a colleague and a camera in order to document the activities that were on offer and those being carried out by other visitors. In particular I looked at whether political conduct was possible, and if it was, what kind of political conduct was encouraged? Even though capturing practices and performances through visual representations is not particularly easy, pictures were taken to illustrate what was being done during that particular visit and in order to visually enrich the narrative account of the ethnographic visit.

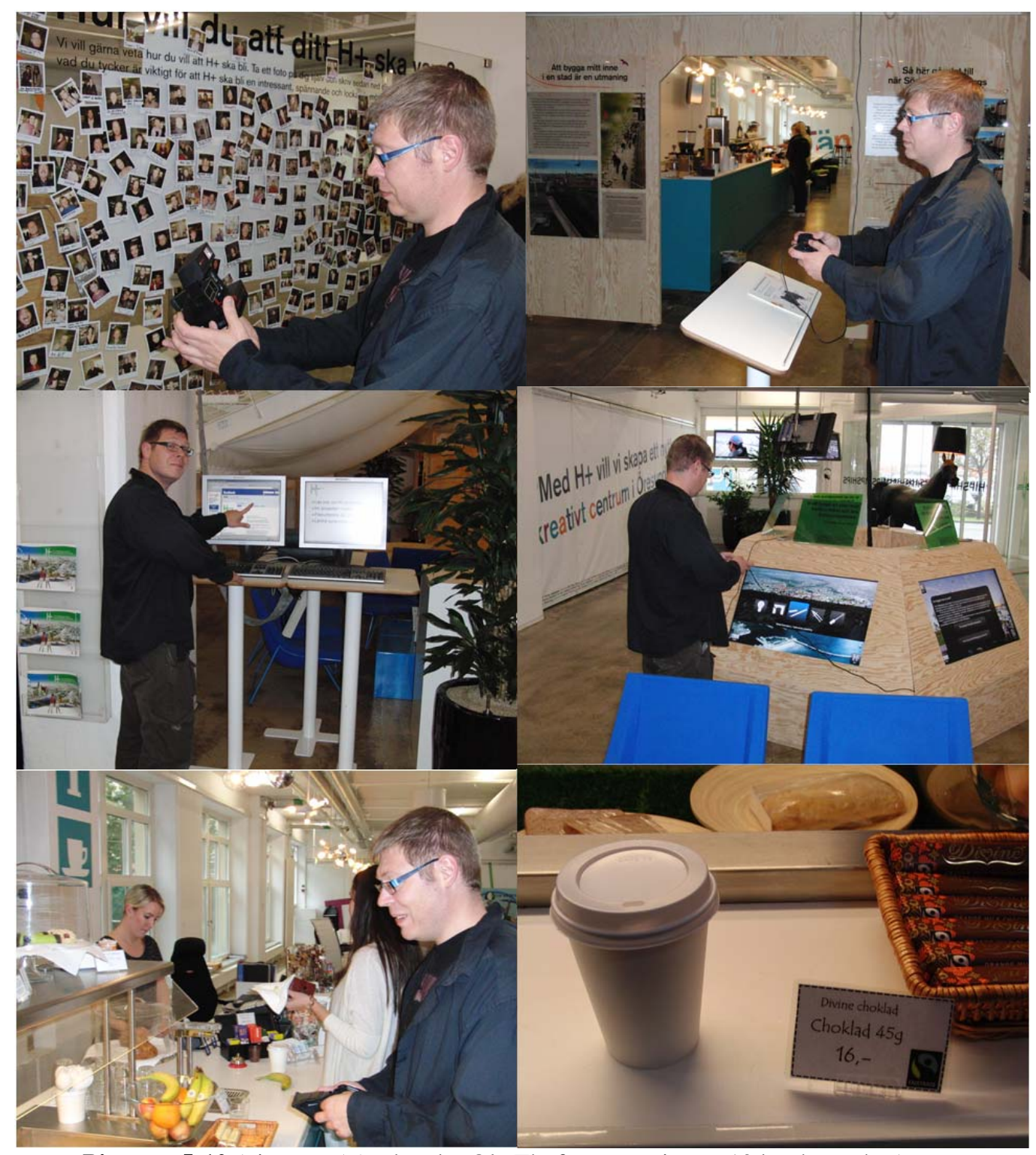

Pictures 5-10 (pictures 5-9 taken by Ola Thufvesson, picture 10 by the author)

My first reaction was that having a cup of coffee was actually the most exciting event - although this is probably an unfair remark. SHIP does offer plenty of opportunities for creativity, at least in a general sense. Meetings can be held at SHIP that have the potential to be creative, students can work undisturbed, there is 
free access to wireless Internet, and there are other ways of socialising. It is mainly a popular place for students, since it is close to the university campus and is clearly an arena for social encounters. Theoretically, as an arena for sociality SHIP offers the foundation for what Richard Florida regards as creativity, namely innovative work that results in economic outcome. Here, for instance, it is possible for the recently established marketing agency to work out innovative marketing campaigns and brand technologies. SHIP is also an arena that matches accounts of the desired prerequisite for creativity - a milieu that encourages and facilitates unexpected meetings (Törnqvist 2004, Tufvessson 2006). In other words, opportunities for creative conduct seem quite good.

But we have to ask ourselves to what degree it is possible to engage in the materially and semantically expressed geographical vision of $\mathrm{H}+$ in a creative way. We have to closely scrutinise the creative activities that can be carried out in order to reveal the possibilities of performing as a political citizen. In this context the impression was different. What you could do was to practically contribute and legitimise the established urban vision, although questioning the vision per se was not very easy. It was also possible to contribute to the collective visioning on the glass wall, and to say what you thought about the future of $\mathrm{H}+$ and Helsingborg. The wording on the glass wall says 'What do you want your $\mathrm{H}+$ to look like? We really want to know what you want $\mathrm{H}+$ to be like. Take a photo of yourself and then write down your hopes and dreams for how $\mathrm{H}+$ can become an interesting, exciting and attractive meeting-place for all citizens in Helsingborg' (my translation). In order to do this, however, the camera has to work; something that it did not do during our visit. Actually, practically none of the interactive technology worked, which made it difficult to assume any kind of political stance, negative or positive. As I have visited SHIP several times I know that the flawed technology was not limited to the specific day this investigative visit was conducted. The technology never seems to work, because for some reason it is not very well looked after by the staff.

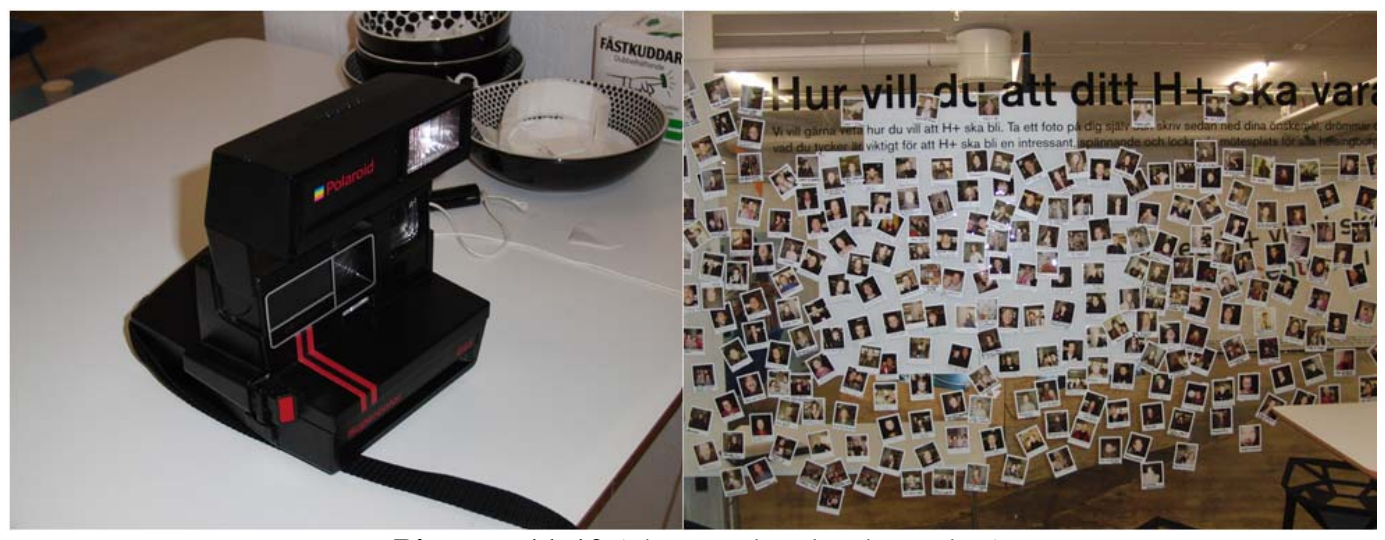

Pictures 11-12 (photos taken by the author) 
To conclude this section I would argue that the showroom has a performative power on the people who visit it, in the sense that it is practically difficult to do anything (although the coffee machine always seems to work). The visitor can of course study the information about the $\mathrm{H}+$ project, look at the models of the future city of Helsingborg and read the different planning documents that are displayed here and there in the locality. In this sense the showroom is primarily a planningscape where the visitor can passively receive information from the planner experts about the future of the city. The showroom thus works in a similar way to fashion and retail showrooms by offering a space in which to show off.

\section{Conclusion - Or an Attempt at Wrapping Something up that has Just Started}

As stated at the beginning, this article reflects the initiation of a research project, which means that the ideas evoked in it are necessarily tentative. There are two main trajectories of thought that I would like to follow-up in this conclusion, both of which are analytical and questioning in nature. The first trajectory of thought, or lines of though-flight if you wish, is the postpolis concept as an umbrella term with which to catch the current state of the polis (see also BAVO 2009). Clearly, there is both a pedagogic and an analytical challenge in connecting highly abstract politico-economic and politico-philosophical ideas and theories with empirical and ethnographic work (see further Latham 2003). As in many other cases, the spectacular (highly theoretic-philosophical) is also to be found in the mundane, in the non-speculative rhythm of urban change (Massey 2005). The spectacular (here in theories that border on, for some at least, conspiratorial thoughts) is also to be found among the best intentions of planners, architects and politicians who embody the planning apparatus that reproduces and strengthens the post-political and biopolitical contemporary.

This leads us to the second trajectory of thought in this conclusion, which is that the $\mathrm{H}+$ project and the showroom SHIP are socio-material constellations that have been mobilised (with the best intentions) by the planning apparatus in the city of Helsingborg, but that in an analytical vein nevertheless enhance the postpolitical tendency. First, there are no indications that the SHIP showroom encourages a performance that facilitates the unfolding of the political in Rancière's meaning of the word. The activities that are offered and organised in the showroom mainly express and perform a neoliberal and market-oriented agenda. For instance, the repeated lunchtime events deal with topics like how to start your own business, how to be an entrepreneur, how to create a brand and so on. The creativity that is fostered at SHIP is the kind of instrumentalist creativity that is inherently connected with profit, business and the entrepreneurial discourse stressing innovation and the invocation of ideas with a market potential. The emphasis on creativity is thus relentlessly contextualized in a post-political 
framework. Creativity here is not about reinventing the societal, reclaiming the political or developing the community approach, but is about nurturing and fostering the individual (biopolitically) as an entrepreneur, employee or owner of an enterprise in the creative industries.

Critically, and tentatively, we must ask ourselves what the relationship is between the post-political and creativity. In the post-political contemporary, political creativity is of no value but has to be channelled into something postpolitical, as it is that kind of creativity that fosters the biopolitical subject as a person that orients and navigates from an ontology that puts the individual before the societal (as in the entrepreneurial discourse). The showroom (as in other arenas in the postpolis) works both ways here, in that it fosters economic individuality and hinders political collectivity (to use Rancière's vocabulary). It also sets up a simulacrum that gives the impression of actual influence over the future urbanity of Helsingborg. By taking a photo of yourself and writing down your hopes and dreams you have done something substantial! Being creative within a simulacrum is not something that threatens the post-political contemporary (Diken 2009a). In short, the showroom becomes a place for shiny, happy people who are distanced from the role and function of the place-engaged political subject and who are instead associated with the cappuccino-subject of the postpolis contemporary.

Richard Ek is Associate Professor at the Department of Service Management, Lund University. His research interests include critical geopolitics, biopolitics, post-politics and place branding. He is currently involved in a project on the visualisation of the post-political citizen in urban renewal projects and in city management. E-mail: Richard.Ek@ism.lu.se.

\section{Notes}

http://www.helsingborg.se/templates/StandardPage.aspx?id=75059\&epslanguage=SV http://www.helsingborg.se/templates/StandardPage.aspx?id=75059\&epslanguage=SV 


\section{References}

Agamben, Giorgio (1998): Homo Sacer: Sovereign Power and Bare Life, Stanford: Stanford University Press.

Anholt, Simon (2007): Competitive Identity: The Brand Management for Nations, Cities and Regions, New York: Palgrave Macmillan.

- (2010): Places: Identity, Image and Reputation, Basingstoke: Palgrave Macmillan.

Barke, Michael \& Ken Harrop (1994): "Selling the Industrial Town: Identity, Image and Illusion”, John R. Gold \& Stephen V. Ward (eds): Place Promotion: The Use of Publicity and Marketing to Sell Towns and Regions, Chichester: John Wiley, 93-114.

BAVO (eds) (2009): Urban Politics Now: Re-imagining Democracy in the Neo-liberal City, NAi Publishers, Rotterdam.

Barry, Andrew, Thomas Osborne \& Nicholas Rose (eds) (1996): Foucault and Political Reason: Liberalism, Neo-Liberalism and Rationalities of Government, Chicago: The University of Chicago Press.

Brenner, Neil (2000): “Building 'Euro-Regions': Locational Politics and the Political Geography of Neoliberalism in Post-Unification Germany”, European Urban and Regional Studies, 7:4, 319-345.

Burgess, Jacquelin A. (1982): “Selling Places: Environmental Images for the Executive”, Regional Studies, 16:1, 1-17.

Butler, Judith (1993): Bodies That Matter: On the Discursive Limits of "Sex", London: Routledge. - (1997a): Excitable Speech: A Politics of the Performative, London: Routledge.

- (1997b): The Psychic Life of Power, Stanford: Stanford University Press. (1999): Gender Trouble: Feminism and the Subversion of Identity, $2^{\text {nd }}$ Edition with an introduction by the author, London: Routledge.

Clarke, David B \& Michael G. Bradford (1989): “The Uses of Space by Advertising Agencies Within the United Kingdom”, Geografiska Annaler B: Human Geography, 71:3, 139-151.

Coaffee, Jon \& Peter Rogers (2008): "Reputational Risk and Resiliency: The Branding of Security in Place-Making”, Place Branding and Public Diplomacy, 4:3, 205-217.

Dahlstedt, Magnus \& Mekonnen Tesfahuney (2009): "Panglossia”, Tidskrift för politisk filosofi, 2009:2, 6-23.

Dean, Jodi (2005): "Communicative Capitalism: Circulation and the Foreclosure of Politics", Cultural Politics, 1:1, 51-74.

(2009): Democracy and Other Neoliberal Fantasies: Communicative Capitalism and Left Politics, Durham \& London: Duke University Press.

Dean, Mitchell (1999): Governmentality: Power and Rule in Modern Society, London: Sage.

- (2007): Governing Societies: Political Perspectives on Domestic and International Rule, Maidenhead: McGraw-Hill.

Dikeç, Mustafa (2005): “Space, Politics, and the Political”, Environment and Planning D: Society and Space, 23:2, 171-188.

Diken, Bülent (2009a): "Radical Critique as the Paradox of Post-Political Society", Third Text, 23:5, 576-586.

(2009b): Nihilism, London: Routledge.

Diken, Bülent \& Carsten Bagge Laustsen (2004): “7-11, 9/11, and Post-politics”, Alternatives, 29:1, 89-113.

(2005): The Culture of Exception: Sociology Facing the Camp, London: Routledge.

Ek, Richard (2003): Öresundsregion - bli till! De geografiska visionernas diskursiva rytm, PhD thesis, Department of Social and Economic Geography, Lund University.

Ek, Richard, Martin Fougère \& Per Skålén (2007): “Revisiting Foucault through Reading Agamben: Implications for Workplace Subjectification, Desubjectification and the Dark Side of Organizations”, paper presented at the $5^{\text {th }}$ Critical Management Studies Conference, Machester 1113 July 2007.

Fischler, Raphaël (1995): “Strategy and History in Professional Practice: Planning as World 
Making”, Helen Liggett \& David Perry (eds): Spatial Practices: Critical Explorations in Social/Spatial Theory, Thousand Oaks: Sage, 13-58.

Florida, Richard (2002): The Rise of the Creative Class, New York: Basic Books.

Foucault, Michel (1978): The Will to Knowledge: The History of Sexuality, Vol. 1, New York: Vintage.

- (1985a): The Use of Pleasure: The History of Sexuality, Vol. 2, New York: Vintage Books. (1985b): The Care of the Self: The History of Sexuality, Vol. 3, London: Penguin.

- (1991): "On governmentality”, Gibson Burchell, Colin Gordon \& Peter Miller (eds): The Foucault Effect: Studies in Governmentality, London: Harvester Wheatsheaf, 97-104.

- (1997): The Politics of Truth, New York: Semiotext(e).

Fukuyama, Francis (1992): End of History and the Last Man, New York: Free Press.

Gregson, Nicky \& Gillian Rose (2000): “Taking Butler Elsewhere: Performativities, Spatialities and Subjectivities”, Environment and Planning D: Society and Space, 18:4, 433-452.

Gunder, Michael (2010): "Planning as the Ideology of (Neoliberal) Space”, Planning Theory, 9:4, 298-314.

Habermas, Jürgen (1984): The Theory of Communicative Action. Volume 1: Reason and the Rationalisation of Society, Cambridge: Polity Press.

- (1987): The Theory of Communicative Action. Volume 2: Lifeworld and System: A Critique of the Rationalisation of Society, Cambridge: Polity Press.

Hannah, Matthew G. (2000): Governmentality and the Mastery of Territory in Nineteenth-Century America, Cambridge: Cambridge University Press.

Harvey, David (1989): "From Managerialism to Entrepreneurialism: The Transformation in Urban Governance in Late Capitalism”, Geografiska Annaler B: Human Geography, 71:1, 3-17. (2003): The New Imperialism, Oxford: Oxford University Press.

Healey, Patsy (1997): Collaborative Planning: Shaping Places in Fragmented Societies, London: Macmillan.

Helsingborgs stad (2010): FÖP H+. Samrådshandling fördjupning av översiktsplan för H+. Maj 2010.

Hudson, Ray (2001): Producing Places, New York: Guilford Press.

Högdahl, Elisabeth (2007): På andra sidan Trädgårdsgatan - om norr och söder i förändringens Helsingborg. Helsingborg: Helsingborgs stad \& Campus Helsingborg.

Jensen, Ole B \& Tim Richardson (2004): Making European Space: Mobility, Power and Territorial Identity, London: Routledge.

Kotler, Phlip, Donald Haider \& Irving Rein (1993): Marketing Places, New York: Free Press.

Landry, Charles (2000): The Creative City: A Toolkit for Urban Innovators, London: Earthscan. (2006): The Art of City-Making, London: Earthscan.

Latham, Alan (2003): "Urbanity, Lifestyle and Making Sense of the New Urban Cultural Economy: Notes from Auckland, New Zealand”, Urban Studies, 40:9, 1699--1724.

Lloyd, Moya (2010): “Judith Butler (1956-)”, Jon Simons (ed): From Agamben to Žižek: Contemporary Critical Theorists, Edinburgh: Edinburgh University Press, 77-92.

Magnusson, Håkan (1994): “Regionerna i forskningen”, I Blickpunkten, nr 1, 36-39.

Massey, Doreen (2005): For Space, London: Sage.

Mahtani, Minelle (2004): “Judith Butler”, Phil Hubbard, Rob Kitchin \& Gill Valentine (eds): Key Thinkers on Space and Place, London: Sage, 65-71.

McCann, Eugene J. (2001): “Collaborative Visioning or Urban Planning as Therapy? The Politics of Public-Private Policy Making”, Professional Geographer, 53:2, 207-218.

- (2002): "The Cultural Politics of Local Economic Development: Meaning-Making, PlaceMaking, and the Urban Policy Process”, Geoforum, 33:3, 385-398.

McGuirk, Pauline M. (2000): "Power and Policy Networks in Urban Governance: Local Government and Property-led Regeneration in Dublin”, Urban Studies, 37:4, 651-672.

McKinley, Alan (2010): "Performativity and the Politics of Identity: Putting Butler to Work", Critical Perspectives on Accounting, 21:3, 232-242.

Miller, Peter \& Nikolas Rose (2008): Governing the Present: Administering Economic, Social and Personal Life, Cambridge: Polity.

Miles, Stephen (2010): Spaces for Consumption, London: Sage. 
Mitchell, Katharyne (1996): "Visions of Vancouver: Ideology, Democracy, and the Future of Urban Development”, Urban Geography, 17:6, 478-501.

Mitchell, Katharyne (1997): “Conflicting Geographies of Democracy and the Public Sphere in Vancouver BC”, Transactions of the Institute of British Geographers, 22:2, 162-179.

Mouffe, Chantal (2005): On the Political, London: Routledge.

Peters, Guy B \& Jon Pierre (1994): "Multi-Level Governance and Democracy: A Faustian Bargain?”, Ian Bache \& Matthew Flinders (eds): Multi-Level Governance, Oxford: Oxford University Press, 75-89.

Rancière, Jacques (1999): Disagreement: Politics and Philosophy, Minneapolis: University of Minnesota Press. 126.

_ (2001): “Ten Thesis on Politics”, Theory and Event 5:3.

- (2003): "Politics and Aesthetics: An Interview", Angelaki: Journal of the Theoretical Humanities, 8:2, 191-211.

_ (2004): “Introducing Disagreement”, Angelaki: Journal of the Theoretical Humanities, 9:3, 3-9.

Rose, Nikolas (1990): Governing the Soul: The Shaping of the Private Self, London: Routledge.

- (1999): Powers of Freedom: Reframing Political Thought, Cambridge: Cambridge University Press.

(2006): The Politics of Life Itself: Biomedicine, Power, and Subjectivity in the $21^{\text {st }}$ Century, Princeton: Princeton University Press.

Salih, Sara (2002): Judith Butler, London: Routledge.

Schmitt, Carl (1976): The Concept of the Political, New Brunswick: Rutgers University Press.

- (1985): Political Theology, Cambridge, MIT Press.

Soja, Edward W. (1989): Postmodern Geographies: The Reassertion of Space in Social Theory, London: Verso.

Sparke, Matthew (1998): "From Geopolitics to Geoeconomics: Transnational State Effects in the Borderlands”, Geopolitics, 3:1, 62-98.

Stevenson, Deborah (1999): "Reflections of a 'Great Port City': The Case of Newcastle, Australia”, Environment and Planning D: Society and Space, 17:1, 105-119.

Stone, Clarence N. (1989): Regime Politics: Governing Atlanta, 1946-1988, Lawrence: University Press of Kansas.

Stubbs, Barry, Gary Warnaby \& Dominic Medway (2002): "Marketing at the Public/Private Sector Interface: Town Centre Management Schemes in the South of England”, Cities, 19:5, 317-326.

Swyngedouw, Erik (2005): "Governance Innovation and the Citizen: The Janus Face of Governance-beyond-the-State”, Urban Studies, 42:11, 1991-2006.

- (2008): Where is the Political? Paper based on Antipode Lecture, IBG/RGS annual conference 2007, London, 29 August - 1 September and on James Blaut Memorial Lecture, Annual Conference of the AAG, Boston, 16-21 April 2008.

— (2009): "The Antimonies of the Post-political City: In Search of a Democratic Politics of Environmental Production”, International Journal of Urban and Regional Research, 33:3, 601620.

Tesfahuney, Mekonnen \& Katarina Schough (2008): “Postpolis”, Göran Graninger \& Christer Knuthammar (eds): Samhällsbyggande och integration: Frågor om assimilation, mångfald och boende, Linköping: Linköping University Interdisciplinary Studies, 119-147.

Tewdwr-Jones, Mark \& Allmendinger, Philip (1998): "Deconstructing Communicative Rationality: A Critique of Habermasian Collaborative Planning”, Environment and Planning A, 30:11, 1975-1989.

Thrift, Nigel (2005): Knowing Capitalism, London: Sage.

Thufvesson, Ola (2006): Kreativitetens yttre villkor: Miljö, rörlighet och nobelpristagare, Institutionen för kulturgeografi och ekonomisk geografi, Lunds universitet.

Törnqvist, Gunnar (2004): Kreativitetens geografi, Stockholm: SNS Förlag.

Virilio, Paul (1994): Vision Machine, Bloomington: Indiana University Press. 
Vogt, Erik M. (2006): “Schmittian Traces in Žižek’s Political Theology (and some Derridean Specters)”, Diacritics, 36:1, 14-29.

Ward, Stephen V. (1994): "Time and Place: Key Themes in Place Promotion in the USA, Canada and Britain since 1870”, John R. Gold \& Stephen V. Ward (eds): Place Promotion: The Use of Publicity and Marketing to Sell Towns and Regions, Chichester: John Wiley, 53-74.

(1998): Selling Places: The Marketing and Promotion of Towns and Cities 1850-2000, London: E \& FN Spon.

Žižek, Slavoj (1998): “For a Leftist Appropriation of the European Legacy”, Journal of Political Ideologies, 3:1, 63-78.

(1999): The Ticklish Subject - The Absent Centre of Political Ontology, London: Verso.

(2001): "Psychoanalysis and the Post-Political: An Interview with Slavoj Žižek", New Literary History, 32:1, 1-21.

_ (2002): Revolution at the Gates - Žižek on Lenin - The 1917 Writings, London: Verso. 